\title{
Motivational component and modern trends for quality assurance of mathematical and natural education of pupils - prospective entrants of technical higher education institutions
}

\author{
Kyrychkov Yu. , Kofanova 0. \\ Polytechnic Lyceum of the National Technical University of Ukraine "Kyiv Polytechnic Institute", Kyiv, Ukraine \\ National Technical University of Ukraine "Igor Sikorsky Kyiv Polytechnic Institute" (Igor Sikorsky Kyiv Polytechnic Institute), Kyiv, \\ Ukraine
}

Received: $01.05 .2020 \quad$ Accepted: 24.06 .2020

\begin{abstract}
The content of the "education quality" concept was considered in the article. The problems of mathematical and natural education of pupils of secondary schools and students of the higher education institutions were analyzed. It has been found that their level of training in mathematical and natural subjects (disciplines) remains too low for successful studying in the higher education institutions and this significantly inhibits the process of acquiring the necessary competences. In order to improve the mathematical and natural preparation of pupils and students, taking into account the development of the STEM education concept in the country, it was proposed to enhance the motivational component of education by introducing advanced educational technologies, in particular, project learning, "creating a situation of success", forming the creative personality of the pupil or student, etc. In our opinion, by increasing the motivation and interest in learning, this will help to intensify and increase the efficiency of the educational process, to develop creative cooperation between the student and the teacher, to increase the creative component of the educational process. The main results of the experimental research work on the implementation of the model of "Conflict-free education" conducted at the Polytechnic Lyceum of the National Technical University of Ukraine "Kyiv Polytechnic Institute" were presented. It was found that implementation of the system of level education and level-stage assessment of students' educational achievements optimizes the process of mastering, consolidation and deepening of students' knowledge, contributes to improving the quality of mathematical-natural education, the motivation of students' learning, their creativity and research competence. The 12-point Student Achievement Assessment Scale developed at the Polytechnic Lyceum back in 1991 (it was taken as a basis by Ministry of Education and Science of Ukraine in 2000), has some differences, making the number of conflicts (misunderstandings) between students \& parents and teachers quite low. The presented model is effective for lessons of different types and in classes with different learning profiles.

Keywords: education quality, mathematical and natural education, STEM education, motivation, educational process, conflict-free education, level education, level-stage assessment.
\end{abstract}

\section{Мотиваційна складова і сучасні тенденції забезпечення якості математично-природничої освіти школярів - майбутніх абітурієнтів технічних закладів вищої освіти}

\author{
Киричков Ю. В., Кофанова О. В. \\ Політехнічний ліцей Національного технічного університету України "Київський політехнічний інститут", Київ, Україна \\ Національний технічний університет України "Київський політехнічний інститут імені Ігоря Сікорського" (КПІ ім. Ігоря \\ Сікорського), Київ, Україна
}

Анотація. У статті розглянуто зміст поняття "якість освіти". Проаналізовано проблеми математичноприродничої освіти як учнів загальноосвітніх шкіл, так і студентів закладів вищої освіти (ЗВО). Встановлено, що рівень їхньої підготовки з математичних і природничих предметів (дисциплін) залишається досить низьким

\footnotetext{
Corresponding Author: Kyrychkov Yuriy Vasyliovych. E-mail: plkpi@ukr.net Principal, Polytechnic Lyceum of National Technical University of Ukraine 'Kyiv Polytechnic Institute' 37, Prosp. Peremohy, Kyiv, Ukraine, 03056

Відповідальний автор: Киричков Юрій Васильович. E-mail: plkpi@ukr.net Політехнічний ліцей Національного технічного університету України "Київський політехнічний інститут", просп. Перемоги, 37, м. Київ, Україна, 03056.
} 
для успішного навчання у ЗВО, і це значною мірою гальмує процес набуття ними необхідних компетентностей. 3 метою удосконалення математично-природничої підготовки школярів і студентів, враховуючи розвиток у країні концепції STEM-освіти, запропоновано підсилити мотиваційну складову навчання шляхом впровадження передових освітніх технологій, зокрема, проєктного навчання, "створення ситуації успіху", формування творчої особистості учня, технології співробітництва тощо. Це, на нашу думку, за рахунок підвищення мотивації та інтересу до навчання, сприятиме активізації і підвищенню ефективності освітнього процесу, розвитку творчої співпраці між учнем і педагогом, збільшенню творчої складової освітнього процесу. Представлені основні результати експериментально-дослідної роботи по впровадженню моделі "Безконфліктної освіти", що проводилась на базі Політехнічного ліцею НТУУ "КПІ" м. Києва. Показано, що уведення системи рівневого навчання та рівнево-ступеневого оцінювання навчальних досягнень учнів оптимізує процес засвоєння, закріплення і поглиблення знань учнів, сприяє підвищенню якості математичноприродничої освіти, мотивації навчання учнів, їх креативності й дослідницької компетентності. 12-бальна шкала оцінювання навчальних досягнень учнів, що була розроблена в ліцеї ще в 1991 році і взята за основу Міністерством освіти і науки України у 2000 році, має деякі відмінності, завдяки чому кількість конфрліктів (непорозумінь) між учнями та батьками і вчителями $є$ досить низькою. Представлена модель $є$ ефективною при проведенні уроків різних типів і у класах різних профілів навчання.

Ключові слова: якість освіти, математична та природнича освіта, STEM-освіта, мотивація, освітній процес, безконфліктна освіта, рівневе навчання, рівнево-ступеневе оцінювання.

\title{
Мотивационная составляющая и современные тенденции обеспечения качества математического и естественнонаучного образования школьников - будущих абитуриентов высших технических учебных заведений
}

\author{
Киричков Ю. В., Кофранова Е. В. \\ Политехнический лицей Национального технического университета Украины "Киевский политехнический институт", Киев, \\ Украина, \\ Национальный технический университет Украины "Киевский политехнический институт имени Игоря Сикорского", Киев, \\ Украина
}

\begin{abstract}
Аннотация. В статье рассмотрено содержание понятия "качество образования". Проанализированы проблемы математического и естественнонаучного образования как учеников общеобразовательных школ, так и студентов высших учебных заведений (ВУЗ). Установлено, что уровень их подготовки по математическим и естественнонаучным предметам (дисциплинам) остается довольно низким для успешного обучения в ВУЗе, и это в значительной степени тормозит процесс приобретения необходимых компетентностей. С целью усовершенствования математической и естественнонаучной подготовки школьников и студентов, особенно с позиций развития концепции STEM-образования, предложено усилить мотивационную составляющую обучения путем внедрения передовых образовательных технологий, в частности, проектного обучения, "создания ситуации успеха", формирования творческой личности ученика и технологии сотрудничества. По нашему мнению, повышение мотивации и интереса к учебе будет способствовать активизации и повышению эффективности образовательного процесса, развитию творческого сотрудничества между учеником и педагогом, увеличению творческой составляющей образовательного процесса. Представлены основные результаты экспериментально-исследовательской работы по внедрению модели "Бесконфрликтного образования", которая проводилась на базе Политехнического лицея НТУУ "КПИ" (г. Киев). Показано, что введение системы уровневого обучения и уровнево-ступенчатого оценивания знаний оптимизирует процесс усвоения, закрепления и углубления знаний учащихся, способствует повышению качества математического и естественнонаучного образования, мотивации обучению учащихся, их креативности и исследовательской компетентности. 12-балльная шкала оценивания достижений учащихся, которая была разработана в лицее в 1991 году и взята за основу Министерством образования и науки Украины в 2000 году, имеет некоторые отличия, благодаря чему количество конфликтов (недоразумений) между учениками, родителями и учителями является достаточно низкой. Представленная модель является эффрективной при проведении уроков разных типов и в классах различных профилей обучения.
\end{abstract}

Ключевые слова: качество образования, математическое и естественнонаучное образование, STEMобразование, мотивация, образовательный процесс, бесконфликтное образование, уровневое обучение, уровнево-ступенчатое оценивание. 


\section{Bcmyn}

Вітчизняна наука й освіта рухаються у напрямку тісної асоціації з європейською науковою спільнотою шляхом створення єдиного освітньо-наукового середовища. Отже, перед загальноосвітньою, професійно-технічною і вищою школами країни постають важливі завдання, серед яких - забезпечення відповідної якості освіти, виховання патріотичної молоді, здатної до продуктивної інноваційної діяльності у сучасному глобалізованому світі. Проте певна нестабільність соціальноекономічних процесів у країні, а також складна міжнародна обстановка призвели до гальмування багатьох освітніх реформ i, як наслідок, до відставання країни у впровадженні прогресивного європейського досвіду. Кінець XX - початок XXI століття стали для всього людства періодом великих перетворень, серед яких відзначимо глобальну інформатизацію суспільства, стрімке зростання обсягів наукової інформації, бурхливий технічний прогрес, революції технологій тощо. Все це великою мірою вплинуло і впливає нині на всі рівні освіти - середню, професійно-технічну і вищу.

Складність і нестабільність соціально-економічних і глобалізаційних процесів, що відбуваються в світі, а також все зростаючий антропогенний тиск на навколишнє природне середовище, потенційні небезпеки зміни клімату на планеті, збільшення кількості природних і особливо техногенних катастроф, інші ризики тощо ставлять перед національною освітою, особливо математично-природничого напряму, нові завдання й виклики. За таких умов підвищується роль математики, фрізики, хімії, інформатики і біології на всіх рівнях національної освіти, а, отже, виникає нагальна потреба у забезпеченні високої якості й конкурентоспроможності математично-природничої освіти школярів і у подальшому - студентів.

Проблема забезпечення якості освіти в системах середньої, професійно-технічної і вищої освіти для всіх країн світу завжди стоїть гостро та є надзвичайно важливою, особливо з огляду на те, що в останні роки спостерігається постійне зростання конкуренції на ринку праці. За період незалежності Україна намагалась знайти ефективні стратегії розвитку освіти. Аналізуючи пройдений країною шлях 3 1991 р. по сьогодення, варто відмітити суттєві досягнення у розвитку та підвищенні якості як середньої, так і професійно-технічної та вищої освіти [16].

Якість освіти - дуже важливий показник надання освітніх послуг. Навколо цього показника написано велику кількість наукових праць, зроблено безліч досліджень, але так і не розроблено єдиного понятійно-термінологічного апарату. Тому й продовжуємо спостерігати, що різні автори надають суттєво відмінні тлумачення цього поняття. Це, на нашу думку, пов'язано і з багатомірністю показника, і 3 певною суперечністю його складових.

Велика кількість робіт присвячена розробці змісту питань якості середньої і вищої освіти, а також обґрунтуванню критеріїв і показників, за якими її можна оцінити на національному чи регіональному рівнях. Водночас не акцентувалося уваги на забезпеченні якості математичної і природничої освіти як науково-освітньої бази, наприклад, для вступу абітурієнтів до закладів вищої освіти (3ВО), їх успішного навчання в університеті, а також для подальшої професійної діяльності майбутніх фахівців, особливо технічних спеціальностей. Тому важливим для розв'язування цього складного питання і вирішення проблем, що постали перед математично-природничою освітою, вважаємо, по-перше, розгляд їі як невід'ємної складової національної системи освіти, а, по-друге, врахування при її забезпеченні принципів неперервності, взаємообумовленості, наступності й професійної спрямованості. Крім того, аналіз наукової літератури $[2,4-6,21,25]$ показав, що науковці розглядають якість освіти одночасно 3 позицій процесу і результату.

Не зважаючи на різноманітні тлумачення сутності поняття "якість освіти", більшість дослідників дотримуються думки, що якість освіти це відповідність результатів навчання вимогам, встановленим законодавством, відповідним стандартом освіти та/або договором про надання освітніх послуг [18]. При цьому інтелектуальна складова навчання обов'язково має підсилюватися мотиваційним компонентом, спрямованим на допомогу учню або студенту обрати для себе власні ціннісні орієнтири; на ініціювання його бажання отримувати знання і вміння, набувати необхідні для успішної самореалізації компетентності. На думку багатьох учених і, зокрема, Л. Оршанського [9], перед сучасною вітчизняною освітою стоять такі важливі завдання, як:

- приведення її у відповідність з інноваційною моделлю соціально-економічного розвитку країни;

- адаптація освіти до запитів споживачів і надавачів освітніх послуг; 
- приведення її у відповідність до вимог конкуренції на ринках освітніх послуг, праці та інновацій.

У зв'язку з цим однією із сучасних тенденцій у реформуванні вітчизняної освіти $є$ цільове спрямування на підвищення їі якості й конкурентоспроможності випускника школи, суспільства, держави в цілому. Провідну роль в цьому відіграють дисципліни, що відносяться до математично-природничої галузі. Проте якість такої підготовки не відповідає сьогоднішнім запитам. Так, згідно з результатами PISA-2018, базового рівня (тобто мінімального, якого наприкінці 9-го класу мають досяпти учні) не досягли:

- 3 математичної грамотності - 36 \% українських підлітків;

- з природничо-наукової грамотності - 26,4 \% [19].

Результати $3 \mathrm{HO}$ останніх років свідчать, що середній бал з математично-природничих дисциплін знаходиться на рівні 140 балів, а більше 15 \% випускників не можуть набрати мінімально прохідний бал.

Одна з причин такого становища, на нашу думку, полягає в тому, що при викладанні дисциплін математично-природничого напряму учні не отримують відповіді про застосування набутих знань на практиці, в реальному житті. Також на такий результат суттєвий вплив мають невизначеність учнів із майбутньою спеціальністю, застарілість навчальних програм, а також відношення учнів і студентів перших курсів 3ВО до цих предметів (дисциплін). Як наслідок, учні не сприймають математичноприродничі дисципліни як такі, що необхідні для набуття профресійних компетентностей, для подальшого вивчення фундаментальних і професійно-орієнтованих дисциплін тощо. Таким чином, одним із першочергових завдань $€$ досягнення того, щоб кожний учень (студент) чітко усвідомлював значущість і необхідність засвоєння змісту навчального матеріалу, його практичні аспекти, зв'язок 3 життям тощо. Тобто потрібно створити мотиваційну основу навчально-пізнавальної діяльності.

Отже, теза про необхідність активізації мотиваційної сфери учнів (студентів) до навчання математично-природничих предметів (дисциплін) не викликає сумніву. Про важливість мотиваційного етапу освітньої діяльності зазначав свого часу ще Я. А. Коменський; а, на думку Н. Ф. Тализіної і П. Я. Гальперіна [20], цей етап мобілізує вольові зусилля й емоційну сфреру учнів, спрямовує певним чином їх діяльність і підсилює їі цілісну роль. В умовах поширення парадигми особистісно орієнтованого навчання, дитиноцентризму визначається, що освітній процес має здійснюватися на засадах індивідуалізації, диференціації, рівневого і профрільного навчання. Сучасне розуміння цих понять вироблялося поступово, протягом тривалого часу. На наш погляд, саме 2000 рік був найбільш визначним, оскільки починаючи з цього року вищеназвані поняття зустрічаються в основних документах Міністерства освіти і науки України (МОНУ). Наприклад:

- 2000 рік - видано наказ МОНУ «Про запровадження 12-бальної шкали оцінювання навчальних досягнень учнів у системі загальної середньої освіти»;

- 2002 рік - затверджено Національну доктрину розвитку освіти;

- 2003 рік - розпочато перехід старшої школи на профільне навчання;

- 2004 рік - затверджено Державний стандарт основної і старшої школи; як експеримент запроваджено зовнішнє незалежне оцінювання (3НО);

- 2011 рік - затверджено Державну цільову соціальну програму підвищення якості шкільної природничо-математичної освіти на період до 2015 року;

- 2014 рік - прийнято Закон України «Про вищу освіту»;

- 2017 рік - прийнято Закон України «Про освіту» ;

- 2020 - прийнято Закон України «Про загальну середню освіту».

Учені зазначають, що для успішного навчання необхідно, щоб у освітньому процесі брало участь якомога більше видів сприйняття [3]. При цьому під «сприйняттям» розуміється процес відображення людиною предметів і явищ навколишнього світу [8]. Починаючи ще з початкової і середньої школи доцільно застосовувати у математично-природничій підготовці учнів новітні способи й методи навчання, прогресивні педагогічні й інфрормаційно-комунікаційні технології, які сприятимуть розвитку творчих здібностей школярів, їх креативності та умінь самостійно отримувати знання й формувати компетентності в освітньо-інфрормаційному і науковому середовищі навчального закладу. На думку Н. І. Труш [17], це є особливо важливим для тих учнів закладів середньої освіти (3СО), які не обрали предмети математично-природничого циклу як профільні предмети i/aбо не планують складати тести ЗНО з них. 
Метою нашого дослідження є розробка й обґрунтування педагогічних підходів до вирішення завдань підвищення якості математично-природничої освіти шляхом розвитку мотиваційної складової навчання учнів, їх креативності й дослідницької компетентності.

\section{II Матеріал і методи дослідження}

До розробки і впровадження педагогічних підходів до вирішення завдань підвищення якості математично-природничої освіти шляхом розвитку мотиваційної складової навчання учнів, їх креативності й дослідницької компетентності був залучений педагогічний колектив Політехнічного ліцею НТУУ «КПІ» м. Києва (далі - Політехнічний ліцей) під керівництвом директора Юрія Киричкова. Перевірка результатів дослідження, а також встановлення адаптаційних механізмів щодо навчання студентів у технічному університеті здійснювалось за участю викладачів кафедри інженерної екології (нині геоінженерії) КПІ ім. Ігоря Сікорського під керівництвом д. пед. н., к. хім. н. проф. Олени Кофанової. Зауважимо, що серед практичних методів дослідження застосовувались такі, як впровадження моделі «Безконфрліктної освіти», опитування й анкетування учнів, порівняльний аналіз успішності навчання.

Під час розробки моделі «Безконфрліктної освіти» особливу роль відіграє розуміння, що сучасне суспільство розвивається в умовах інформатизації й майже глобальної інтеграції, підвищенні запиту на виховання гармонійно розвинених і практично зорієнтованих особистостей. Отже, задача ліцею полягає в тому, щоб забезпечити освітній процес якісними і змістовними навчальними предметами, мотивуючи учнів до навчання.

Відомо, що на навчальну мотивацію впливають технології, методи, прийоми викладання й оцінювання навчальних досягнень учнів. Навчання повинно створювати атмосферу зацікавленості, небайдужості до освітнього матеріалу, сприяти творчому пошуку вирішення навчальних завдань. При цьому вчитель спрямовує свою діяльність на розвиток у вихованців самостійності, гнучкості, критичності, креативності, оригінальності емпіричного і теоретичного мислення тощо.

\section{III Результати}

Сучасна гуманістична парадигма освіти визначає пріоритет становлення особистості, задоволення ії освітніх потреб. Саме цьому в найбільшій мірі і сприяють система рівневого навчання і система рівнево-ступеневого оцінювання навчальних досягнень учнів, що проходили апробацію в Політехнічному ліцеї НТУУ «КПІ» м. Києва.

Ідея рівневого навчання відображує необхідність підвищення ефрективності освітнього процесу, якості освіти учнів. Рівневе навчання надає можливість учителеві навчати учнів на різних рівнях складності (репродуктивному, перехідному, творчому) і завдяки диференційованому підходу створювати кожному з них у процесі навчання ситуацію успіху. Ї̈̈ переваги також і в тому, що якість навчання учнів узгоджується між самими учасниками освітнього процесу, передбачає формування їх індивідуальних траєкторій навчання.

Для оцінювання навчальних досягнень учнів в ліцеї з 1991 року використовується 12-бальна шкала, яка має багато спільного з тією, що введена МОНУ у 2000 році, але має і деякі відмінності. Для повноти висвітлення цього питання потрібно відзначити, що досвід використання даної системи оцінювання в Політехнічному ліцеї вивчався МОНУ перед запровадженням ії̈ по всій Україні.

12-бальна шкала, що використовується в Політехнічному ліцеї, має 4 рівні та 3 ступені (табл. 1). Вчителі повністю використовують рівневі критерії до оцінювання навчальних досягнень учнів, а оцінювання в середині рівня відбувається за схемою «задовільно», «добре» і «відмінно».

Запропонована і вживана нами система диференційованого оцінювання навчальних досягнень $\epsilon$ зрозумілою учням (що вже суттєво зменшує конфліктність при навчанні), а ознайомлення ліцеїстів із принципами побудови завдань сприяє і кращому засвоєнню матеріалу, і формуванню у них логічного мислення, креативності тощо. Принцип поділу смислового ядра на чіткі, логічні програми, змістовно насичені смисловими одиницями, допомагає учням краще зрозуміти і засвоїти навчальний матеріал, акцентувати увагу на ключових поняттях, явищах, процесах навчального матеріалу. Смислові одиниці це інформаційно самостійні, логічно обгрунтовані, завершені частини навчального матеріалу певної теми чи розділу. 
Табл. 1. 12-бальна шкала оцінювання, що використовується в

Політехнічному ліцеї НТУУ «КПІ» м. Києва

\begin{tabular}{|c|c|c|c|c|c|}
\hline \multirow[t]{2}{*}{ Рівні / Ступені } & \multicolumn{4}{|c|}{ Рівні складності } & \multirow[t]{2}{*}{ Якісні оцінки } \\
\hline & $\mathrm{I}$ & II & III & IV & \\
\hline \multirow{3}{*}{ Ступені } & 3 & 6 & 9 & 12 & «відмінно» \\
\hline & 2 & 5 & 8 & 11 & «добре» \\
\hline & 1 & 4 & 7 & 10 & «задовільно» \\
\hline
\end{tabular}

Вчителями ліцею перероблені навчальні програми з предметів за системою рівневого навчання. Отже, кожна тема включає:

- зміст навчального матеріалу теми за програмою;

- пояснювальну записку;

- вимоги до знань, умінь і навичок, розподілені на смислові одиниці та їх складові по чотирьох рівнях складності у вигляді таблиць;

- основні питання до теми, розподілені по рівнях і смислових одиницях;

- орієнтовні варіанти тематичних рівневих завдань;

- рекомендовану до теми літературу.

Технологія укладання завдань за принципом смислового ядра передбачає, що його зміст і зміст кожної смислової одиниці може бути логічно, обґрунтовано поділено на чотири рівні складності (визначені рівневими вимогами). Основний зміст, ключові події, факти, поняття, явища, процеси тощо визначаються і простежуються на кожному рівні. На кожному наступному рівні від учня вимагається більший обсяг знань і глибше розуміння матеріалу, вищий рівень умінь і навичок - від уміння визначати ключові події і факти, розкривати поняття до вміння характеризувати, узагальнювати, аналізувати явища і процеси, висловлювати власні думки й надавати оцінки, виявляти творчий підхід тощо.

Однак перед кожним педагогом постає складне питання - на якого учня орієнтуватися під час навчального процесу? Якщо основний акцент зробити на сильних учнів (а таких, як правило, небагато), то інші будуть не встигати за поясненнями вчителя, і кожний урок для них буде засвоєний не в повній мірі; а для слабких учнів такий урок буде взагалі безнадійно втрачений. Тому в більшості випадків вчитель орієнтується на так званого середнього учня групи (класу). Але при цьому спостерігається інша ситуація - рівень знань учнів задовільний, але і зацікавленість сильних учнів до предмета знижується або втрачається зовсім.

Складним з точку зору організації, але ефективним видом диференційованого навчання $є$ здійснення поділу одного класу при вивченні окремих предметів на декілька різнорівневих груп, які формуються залежно від рівня навчальних досягнень і здібностей учнів з кожного профрільного предмету. В рамках даного експерименту в ліцеї було створено різнорівневі групи та здійснено предметну диференціацію з математики, фізики, інформатики, української і англійської мов, науковопрактичної роботи за особистісно зорієнтованим підходом. Заняття з кожного предмету проводилося в двох групах одночасно двома різними викладачами. Майже на кожному уроці учні мали можливість переходити з однієї групи в іншу в залежності від свого рівня навчальних досягнень з предмету.

Наприкінці навчального року було підведено підсумки та проведено аналіз результатів експерименту. Вчителі відмітили, що успішність і дисципліна на уроках покращились; учні уважніше слухали пояснення вчителя, виявляли зацікавленість при вивченні нового матеріалу. Завдяки такому переформуванню класів ліцеїсти почали проявляти більшу зацікавленість і самостійність; у них значно підвищився інтерес до навчання. I особливо це було помітно саме при вивченні предметів математичноприродничого напряму.

На кожному занятті обов'язково проводилося опитування учнів з теоретичного матеріалу, перевірялося виконання домашніх завдань і давалося пояснення незрозумілих питань. Іноді учні перевіряли завдання один у одного, що давало можливість перевірити знання обох учнів відразу. Слід також відзначити активність, яку учні почали виявляти при подачі нового матеріалу - вони не боялися виходити до дошки, розв'язувати зовсім нові, поставлені перед ними завдання, жваво їх обговорювали, 
знаходили і виправляли допущені помилки. Часто учні пропонували декілька способів розв'язання однієї і тієї ж задачі і шляхом обговорення обирали найбільш раціональний спосіб її розв'язання. Деякі учні навіть самі придумували нові умови задач, а інші - їх тут же розв'язували.

На практичних заняттях кожний учень отримував рівневі завдання, самостійно обираючи бажаний рівень. За необхідності учень міг отримати підказку, яка допомагала виправити помилку. При оголошенні домашнього завдання учням вказувалися обов'язкові до виконання завдання і додаткові, які бажано виконати для кращого засвоєння матеріалу.

Працюючи з групами учнів, які показували нижчі результати, вчителі використовували такі інноваційні методи навчання, як метод розвитку критичного мислення, проблемно-пошуковий метод тощо. Для забезпечення якісного навчання проводились такі типи уроків, як урок-гра, урок-конкурс, урокдослідження. На заняттях постійно використовувалися інтерактивні технології навчання - робота в групах, парами, проблемно-пошуковий діалог та інші. Позитивним є досвід використання інформаційнокомунікаційних технологій (IKT). При цьому домінуючими методами навчання на уроках з математики, фізики, хімії, інфрорматики, біології тощо були бесіда, вправи і робота з підручником. Пояснення учням шляхів обробки і збереження інформації, удосконалення знань, умінь і навичок спиралося на теоретичний матеріал підручника, виконання вправ за поданим зразком, виконання комплексних, конструктивних вправ на етапі систематизації й узагальнення вивченого, причому, обов'язково 3 урахуванням особливостей учнів. На уроках пізнавальна діяльність послідовно змінювалася 3 репродуктивної на реконструктивну й творчу.

Таким чином, серед основних результатів впровадження моделі «Безконфліктної освіти» у Політехнічному ліцеї, відзначимо такі:

- виникла або поглибилися здорова конкуренція серед учнів;

- учні отримали можливість реалізувати себе у пізнанні, навчальній діяльності, поведінці;

- вчителі змогли знайти такі засоби і методи організації освітнього процесу, які врахували потреби кожної дитини;

- вдалося більш повно врахувати особливості психічного розвитку дітей;

- учні набули необхідних компетентностей за індивідуальними траєкторіями навчання;

- поглибилася гуманізація змісту навчання;

- покращилися системність та інтегрованість знань, забезпечено узгодження наукових і навчальних знань і вмінь;

- з переважної кількості предметів математично-природничого напряму вдалося перевести учнів на більш високий рівень навчальних досягнень або в межах цього ж рівня на більш високий ступінь засвоєння навчального матеріалу.

Працюючи багато років з питань розвитку академічних здібностей учнів, доходимо висновку, що ліцеїсти, «нафраршировані знаннями» не завжди є конкурентоспроможними і успішними у подальшому житті. Лише заучуючи фактичний матеріал, неможливо винайти щось абсолютно нове, інноваційне; потрібно уміти ці факти аналізувати, порівнювати, узагальнювати, критично оцінювати і застосовувати в житті. Навчання це не просто передача учням готових знань від учителя або книги, це можливість знаходити нетрадиційні, новаторські рішення і способи розширення свідомості учнів.

Отже, з огляду на історію виникнення STEM-освіти і на етапи її впровадження в різних країнах, було вирішено спробувати застосувати метод інтеграції навчального матеріалу 3 математичноприродничих предметів у навчальному процесі. Тому впродовж останніх трьох років у практику роботи Політехнічного ліцею було впроваджено такі форми STEM-навчання:

- інтегровані уроки;

- тематичні дні;

- дослідно-проектну діяльність;

- екскурсії, хакатони, фестивалі тощо.

STEM-підхід в освітньому процесі середньої і старшої школи надав змогу учням отримувати знання і уміння, набувати необхідних компетентностей через візуалізацію наукових явищ, процесів і технологій, легко й глибокого зрозуміти складні наукові теорії і процеси. STEM-освіта не лише звертає увагу на природничі науки й інноваційні технології, але активно розвиває критичне мислення і творчу складову особистості. 


\section{IV Обговорення}

Думки щодо активізації навчання за рахунок підвищення мотивації учнів, спрямування їх на активні форми навчання висловлювались багатьма вченими впродовж усього періоду становлення педагогічної науки. Відзначимо, зокрема, праці Я. Коменського, Й. Песталоцці, Д. Дьюі, К. Д. Ушинського та інших учених. У наш час питання активізації навчання, а також аналізу різноманітних чинників підвищення його результативності розглядаються такими вченими, як А. Алексюк, А. Вербицький, А. Дьоміна, І. Лернер, О. Савченко, М. Скаткин, О. Ярошенко тощо. Проблеми забезпечення якості освіти висвітлено у працях І. Зязюна, Л. Карамушки, Т. Лукіної, О. Ляшенко, Н. Ничкало та інших учених, які акцентували увагу на необхідності забезпечення конкурентоспроможності вітчизняної освіти.

Великого значення математично-природнича освіта набуває і в соціально-економічному й політичному розвитку країни, особливо з огляду на те, що в умовах глобалізації на перший план виходить інноваційно-технологічна діяльність людини, а також відбувається бурхливий розвиток інформаційно-комунікаційних технологій, автоматизації і діджиталізації виробництв, зростання обсягів наукової інформації. Проте, як зазначають учені, нині спостерігається значне спадання рівня підготовки старшокласників, випускників 3СО і технікумів, студентів 1-2-го курсів навіть технічних спеціальностей 3 дисциплін математично-природничого спрямування, причому не тільки в нашій країні.

Мотивацію учнів до навчання математичним і природничим предметам можна підняти розвитком креативності учнів завдяки, наприклад, впровадженню в освітній процес практичних завдань і/або лабораторних робіт дослідницького характеру, нових прогресивних освітніх технологій тощо. Це, в свою чергу, надасть змогу не тільки сорормувати науковий світогляд учня, набути необхідних компетентностей, а й розвинути його особистість, виробити певний стиль мислення, готовність у майбутньому правильно розв'язувати складні й важливі життєві задачі, надасть змогу наблизити навчання до життя. Неперервність і вдосконалення освітнього процесу може бути забезпечено створенням і функціонуванням невеликих науково-дослідницьких колективів - наукових гуртків. Їх діяльність спрямовують на розширення границь навчального матеріалу та враховує новітні тенденції у розвитку освіти, передбачає впровадження ефективних освітніх технологій тощо.

Сьогодні в Україні широкого розвитку набуває особистісно орієнтоване навчання, основи якого розробив відомий вітчизняний дослідник І. Бех [1]. Модель особистісно орієнтованого навчання передбачає таку організацію освітнього процесу, щоб кожен учень міг вести пошук, конкретизувати способи власної діяльності, застосовувати їх для розв'язування навчальних і практично спрямованих завдань, обґрунтовувати свої дії. У такому разі учень стає суб'єктом навчання у освітньому процесі, а роль учителя (викладача) перетворюється на організатора й керівника самостійної творчої діяльності учня [1,28]. Окрім того, особистісно орієнтоване навчання передбачає диференційований підхід, який базується на врахуванні індивідуальних здібностей учня, рівня його попередньої підготовки з певного предмету чи блоку предметів (фізико-математичний, природничий блоки тощо), особистісний досвід учня, його навчально-пізнавальні інтереси і працездатність [27]. Отже, пріоритетним у такому навчанні $\epsilon$ індивідуальність учня, його мотивація, а також спрямованість освітнього процесу на розвиток його творчої активності, формування пізнавальних здібностей тощо. Освітні технології, які дають змогу інтенсифікувати навчально-виховний процес як у середній, так і у вищій школах досліджували, зокрема, В. Беспалько, А. Нісімчук і О. Падалка, О. Пєхота, Г. Селевко, С. Сисоєва та інші вчені. Найбільш перспективними з точки зору підвищення мотивації учнів до навчання математичним і природничим предметам (дисциплінам) вважаємо такі освітні технології, як "створення ситуації успіху", формування творчої особистості учня, різноманітні проектні технології, а також технологія співробітництва [10]. Розглянемо ці освітні технології детальніше. Зокрема, головною метою технології "створення ситуації успіху" є така побудова освітнього процесу, щоб створити умови для творчого розвитку особистості учня (студента), надати йому можливість відчути успіх, повірити у свої сили та найповніше реалізувати свої здібності. Вчені зауважують, що "ситуація успіху" досягається лише тоді, коли сам учень (студент) задоволений отриманим результатом, тобто відзначає його як успіх. Зокрема, І. Бех попереджував, що неможливо сформувати позитивну особистість у діяльності, яка приносить тільки невдачі. А О. Пєхота зазначає, що основою цієї технології $€$ створення позитивної обстановки під час занять, пошук перспективних ліній розвитку учня, зосередження на його здобутках, а не на вадах [11, с. 204-211]. 
Така освітня технологія, як "фрормування творчої особистості" передбачає виховання людини, здатної до самостійного мислення, генерування нових ідеї, приймання нестандартних відповідальних рішень. Технологія базується на визнанні того, що творча особистість - "...це індивід, який володіє високим рівнем знань, має потяг до нового, оригінального" [10, с. 99]. Для такої особистості творча діяльність $€$ життєво необхідною, але головною ознакою $€$ наявність у учня творчих здібностей (індивідуально-психологічних здібностей, які відповідають вимогам творчої діяльності і $\epsilon$ умовою їі успішного виконання) [15]. Зрозуміло, що творчі здібності людини пов'язані із створенням чогось нового, причому це, як правило, супроводжується пошуком нових засобів діяльності. Технологія супроводжується досягненням задоволення учнів результатами власної діяльності, створенням умов для їх зацікавленості предметом, розвитку їх природних здібностей.

В основі проектної діяльності (проекту) лежить виконання учнем (студентом) певного виду діяльності навчального або дослідницького спрямування. Робота над проектом може бути і частиною навчального процесу з певного предмету, і складовою наукової діяльності. Проте в основі роботи завжди лежить зацікавленість учня (студента) певною темою, напрямком або певним видом праці; самостійне здобуття знань; пошук нових, оригінальних ідей тощо. Важливою $є$ організація зворотного зв'язку (наприклад, індивідуальні консультації, запровадження, наприклад, технології портфоліо, інформаційно-комунікаційних технологій тощо).

Дослідники виокремлюють такі види проектів, як науково-дослідницькі, творчі, ігрові, інформаційні або практико-орієнтовані [11, с. 150-155]. Проектна діяльність може здійснюватися індивідуально або у малих чи достатньо великих колективах. Це надає можливість формувати у учнів здатність працювати у колективі (або парами), поважати думку своїх колег, цінити їх знання й уміння, розвивати комунікативні здатності, вдосконалювати інтелектуальний рівень тощо. Встановлено, що застосування проектних технологій значно підвищує мотивацію до навчальної діяльності, сприяє освоєнню нових методів пізнання, розвитку комунікативних якостей, вихованню творчої особистості тощо [10, с. 101].

Цікавою для підвищення мотиваційного компонента вивчення математичних і природничих предметів $є$ технологія співробітництва, яка має власний погляд на особистість учня. На думку вчених, особистість у людини формується вже в дитинстві, а тому, за цією технологією, особистість виявляється суб'єктом, а не об'єктом навчання й виховання. Тобто саме особистість є метою, а не засобом для досягнення будь-якої мети [26, с. 40-45]. Технологія співробітництва сприяє розвитку творчих і організаційних здібностей людини, формує критичне мислення учнів тощо [14]. А головною перевагою технології $€$ рівноправні відносини між учнем і вчителем, що сприяє кращому розумінню матеріалу і зростанню мотивації.

Зазначимо, що майже всі освітні технології передбачають застосування різних методів навчання. Наприклад, це можуть бути диспути, бесіди, круглі столи, робота в парах, мозковий штурм, ігрові заняття, тести, наукові дослідження (колективні або індивідуальні), розв'язання ситуативних завдань, проблемне навчання тощо. У сучасному світі цифрових технологій особливого значення набуває інтерактивне навчання. О. Пометун та Л. Пироженко під інтерактивним навчанням розуміють навчання в режимі діалогу всіх учасників освітнього процесу, під час якого відбувається їх творча взаємодія 3 метою досягнення взаєморозуміння, вироблення спільних підходів до розв'язування поставлених завдань, розвитку особистості учня. При цьому, на думку авторів, важливим $є$ використання ситуативних завдань, моделей життєвих ситуацій, ігрових технологій тощо [12,-13].

М. Кларин акцентує увагу саме на діалоговому навчанні, в ході якого відбувається взаємодія вчителя та учня [22]. Тому, спираючись на дослідження провідних вітчизняних і зарубіжних учених, на заняттях з математики, фрізики, хімії, біології та інших дисциплін математично-природничого спрямування і у середній школі (ліцеї), і у ЗВО (зокрема, у КПІ ім. Ігоря Сікорського) для підняття інтересу і мотивації учнів і здобувачів вищої освіти до навчання, розвитку їх творчого потенціалу широко застосовуємо IKT. Це сприяє інтеграції навчального матеріалу з математичних і природничих наук, їх взаємопроникненню, а також забезпечує успішне пізнання навколишнього середовища, його законів i тенденцій.

На уроках з природничих дисциплін, зокрема, фізики, хімії, біології тощо, для підняття мотивації учнів до навчання вважаємо за доцільне використовувати різнопланові дискусії і диспути. Так, при підготовці до обговорювань рекомендуємо учням знайти інформацію в мережі Інтернет, наукових 
статтях та методичних розробках провідних учених. При цьому педагог бере на себе роль організатора і помічника у підборі матеріалу, формулює основні питання, оцінює якість підготовки учня (студента), звертає увагу на його власні думки, обговорює з колективом суперечливі питання, допомагає у розв'язанні певних конфліктних ситуацій, які можуть виникнути при обговоренні доповіді або під час диспуту. При підготовці до дискусій і диспутів активно застосовуємо приклади з життя, проглядаємо відео-файли і моделюємо можливі проблемні ситуації. Все це сприятиме підвищенню мотивації, виробленню спільних або альтернативних думок, розробці шляхів розв'язування проблеми. Моделюючи конкретні життєві ситуації, учні (студенти) виступають у ролі дослідників, їх зацікавленість навчальним матеріалом з теми чи з предмету (дисципліни) загалом суттєво зростає [7].

На уроках з математики, фрізики і хімії активно використовуємо метод "мозкового штурму" (брейнстормінг - brain storming), коли учні (студенти) у невеликих групах чи навіть всі разом (залежно від загальної кількості студентів у групі чи учнів у класі) обговорюють певну проблемну ситуацію або навчальне завдання. Завданням педагога і експертів при цьому $\epsilon$ фіксування наданих учнями пропозицій або висловлених думок, не критикуючи і не оцінюючи їх. Тобто вчитель спрямовує дискусію у креативне русло, іноді провокуючи доповідачів; надає можливість всім бажаючим висловлювати й обґрунтовувати свої навіть франтастичні ідеї. На заключному етапі заняття експерти складають список висловлених ідей та відбувається їх оцінювання з метою вибору найкращих.

Круглі столи вважають однією з різновидів дискусійних технологій. У такий бесіді, як правило, беруть участь групи по 10-15 осіб, а керує ними вчитель або обраний класом представник. Метою обговорення за круглим столом не обов'язково є розв'язання певної проблеми чи проблемної ситуації. Завданням такої бесіди є збір наукової чи статистичної інформації, поглиблення теоретичних знань 3 предмету (дисципліни), розвиток науково-дослідницьких компетентностей учнів (студентів) та їх здібностей. Учні (студенти) обговорюють і традиційні шляхи вирішення проблеми, а також шукають нові й перспективних напрямки та ідей її розв'язання.

Важливим $є$ й те, що в процесі розгляду прикладних і модельних завдань формується критичне мислення учнів (студентів), реалізується потреба в оцінюванні результатів власної пошукової діяльності та діяльності своїх колег. Проте, створюючи проблемні ситуації, педагог повинен слідкувати, щоб завдання відповідали рівню знань учнів (студентів), їх інтелектуальним можливостям тощо, а також щоб завдання не були стереотипними або відірваними від життя. Тобто саме на вчителі лежить відповідальність за успіх круглого столу або іншого виду дискусійної роботи.

Отже, при плануванні практичних, семінарських та/або лабораторних занять 3 предметів (дисциплін) математично-природничого циклу необхідно створювати умови для реалізації таких методологічних прийомів, як:

- використання різноманітних технічних засобів навчання, мережі Інтернет, відео-уроків тощо;

- ефективне використання навчального потенціалу самостійної роботи учнів (студентів), у тому числі й із застосуванням можливостей IKT;

- активізація зацікавленості учнів (студентів), створення на заняттях ситуації успіху;

- підтримка роботи у колективі, парами або малими групами;

- залучення до дискусій і диспутів "слабких" або неактивних учнів (студентів), надання їм завдань, які відповідають їхньому інтелектуальному рівню;

- пошук інноваційних методів "пробудження" зацікавленості учнів (студентів) матеріалом математично-природничої спрямованості, наприклад, шляхом оформлення індивідуальних або групових портфоліо з курсу.

Науково-дослідницька робота учнів (студентів) також $€$ важливою складовою навчального процесу, оскільки вона спрямована на формування необхідних ключових і предметних компетентностей, сприяє здобуванню й накопиченню особистого досвіду. Ми поділяємо думку І.Я. Лернера про те, що досвід творчої діяльності не можна передати розповідями або показами якогось процесу, що здійснюються на очах учнів (студентів). Поки людина не бере участі у процесі творчої і пошукової діяльності, він цього досвіду не набуває. Отже, задля розвитку творчих здібностей учнів (студентів) ми намагаємось залучати їх у спеціально організований науково-пізнавальний процес, який є моделлю наукового процесу пізнання [23, 24]. 


\section{V Висновки}

Таким чином, вище викладене дозволяє зробити такі висновки:

1. Забезпечення якості освіти $є$ складним і багатоплановим завданням, яке залежить від багатьох різноманітних чинників, серед яких, наприклад, особистісні й професійні якості педагога, технічне й інфрормаційне забезпечення освітнього процесу, методична, мотиваційна та інтелектуальна складові, а також адекватні методи контролю успішності тих, хто навчається, соціально-економічні відносини у суспільстві тощо.

2. Сучасна педагогічна наука має в своєму арсеналі велике різноманіття інноваційних методів і технологій навчання, ефективність впровадження яких у навчально-виховний процес великою мірою залежить не тільки від тих, хто здобуває освіту (середню, вищу, професійну), а й багато в чому від самого педагога, його кваліфікації, доброзичливості, прагнення до інноваційної діяльності тощо. Заняття мають захоплювати учнів (студентів), формувати у них зацікавленість навчальним матеріалом, пробуджувати інтерес до самостійного отримання знань, вироблення критичного мислення i особистісних якостей.

3. Мотиваційна складова є дуже важливою при вивченні предметів (дисциплін) математичноприродничого профілю, а застосування особистісно орієнтованого навчання і сучасних інтерактивних технологій надає можливість активізувати пізнавальну діяльність учнів (студентів), вилучити малоефективні, екстенсивні способи передачі знань, надати впевненості у своїх силах.

4. Особистісно орієнтоване навчання забезпечує неперервний розвиток інтелектуальних і особистісних якостей учнів (студентів), їх саморозвиток і самовдосконалення. За такого навчання всі учасники освітнього процесу активно взаємодіють між собою, обмінюються інформацією і досвідом задля спільного розв'язування навчальних проблем чи проблемних завдань.

Правильне використання інноваційних методів і технологій навчання дає змогу створювати необхідні педагогічні умови для розвитку здібностей учнів (студентів), набуття ними необхідних знань і компетентностей, розширення інтелектуального й мотиваційного компонентів навчання саме математиці й природничим дисциплінам; сприятиме розвитку творчого потенціалу i, як наслідок, підвищенню результативності навчання.

\section{Бібліографічні посилання}

1. Бех І. Д. Виховання підростаючої особистості на засадах нової методології. Педагогіка і психологія. 1999. С. 5-14.

2. Бєлих О. М. Особливості управлінської діяльності в системі освіти. Актуальні питання освіти і науки: зб. наук. ст., матер. IV міжнар. наук.-практ. конф., 10-11 листоп. 2016 р. Харківський нац. економічний ун-т імені Семена Кузнеця. C. 34-38.

3. Жигайло О., Рудник Т. Особливості використання навчальних посібників на різних етапах уроку математики у початковій школі. Актуальні питання гуманітарних наук. вип. 16, 2016 С. 316-321.

4. Лукіна Т. Вимірювання й управління якістю освіти: навчально-методичні матеріали. К.: Експрес-об'ява, 2007. 50 с.

5. Лукіна Т. Моніторине якості освіти: теорія і практика. К.: Вид. дім «Шкільний світ»; Вид-во Л. Галіцина, 2006. 128 с.

6. Ляшенко О. І., Лукіна Т. О., Булах І. Є., Мруга М. Р. Методика і технології оиінювання діяльності загальноосвітнього навчального закладу. посібник. К.: Пед. думка, 2012. 160 с.

7. Микитюк О. М. Теорія і практика організації науково-дослідної роботи у вищих навчальних закладах освіти України. Ін-т педагогіки АПН України. К., 2004. 42 с.

8. Компетентнісний підхід у сучасній освіті: світовий досвід та українські перспективи. Бібліотека з освітньої політики; під заг. ред. О. В. Овчарук. К.: "К.І.С.", 2004. 112 c.

9. Оршанський Л. Про потребу кардинальних змін у галузі вітчизняної освіти. Актуальні питання гуманітарних наук. вип. 16, 2016 C. 371-378.

10. Пастернак Т. А. Виховні технології у сучасному вищому навчальному закладі. Нові технології навчання: наук.метод. зб. / кол. авт. К.: Ін-т інноваційних технологій і змісту освіти, 2007. вип. 47. С. 97-102.

11. Пехота О. М., Кіктенко А. З., Любарська О. М. та ін. Освітні технології: навч.метод. посіб;. за ред. О. М.Пехоти. К.: А.С.К., 2004. $256 \mathrm{c}$.

12. Пометун О., Пироженко Л. Інтерактивні технології навчання: теорія і практика. К., 2002. 136 с.

13. Пометун О., Пироженко Л.. Сучасний урок. Інтерактивні технології навчання. К., 2004. 192 с.

14. Перспективні освітні технології: наук-метод. посіб; ред. Г. С. Сазоненко. К:. Гопак, 2000.560 с.

15. Сисоєва С. О. Основи педагогічної творчості вчителя: навч. посіб. К.: ІСДОУ, 1994. 112 с.

16. Сухомлинська О.В. Періодизація педагогічної думки в Україні: кроки до нового виміру. Розвиток педагогічної $i$ психологічної наук в Україні 1992-2002: зб. наук. праць до 10-річчя АПН України. Х.: ОВС, 2002. ч. 1. С. 37-54.

17. Труш Н. І. Про діалектику взаємовідношення дидактичних принципів науковості та доступності в процесі навчання математики. ежурнал "Педагогічна наука: історія, теорія, практика, тенденції розвитку". 2008. вип. № 2. 
18. Закон України «Про освіту» від 05.09.2017 р. № 2145-VIII. Голос України. 2017. 27 верес. (№ 178-179). С. 10-22.

19. Реформа НУШ дійсно потрібна Україні - результати PISA підтверджують це і вказують, як зробити зміни ефективнішими. Міністерство освіти і науки України. URL: https://mon.gov.ua/ua/news/reforma-nush-dijsno-potribnaukrayini-rezultati-pisa-pidtverdzhuyut-ce-i-vkazuyut-yak-zrobiti-zmini-efektivnishimi (дата звернення 20.12.2019).

20. Управление познавательной деятельностью учащихся, под ред. П. Я. Гальперина, Н. Ф. Талызиной. М.: Изд-во Моск. ун-та, 1972. 262 c.

21. Кальней В.А., Шигов С.Е. Мониторине качества образования. М., Вологда: Изд-во Вологод. ин-та повышения квалификации пед. кадров, 1998. 202 С.

22. Кларин М. В. Интерактивное обучение - инструмент освоения нового опыта. Педагогика. 2000. № 7. С. 43-48.

23. Лернер И. Я. Дидактические основы методов обучения. М.: Педагогика, 1981. 186 с.

24. Лернер И. Я. Процесс обучения и его закономерности. М.: Знание, 1980. 96 с.

25. Поташник М. Качество образования: проблемы и технологии управления (В вопросах и ответах). М.: Пед. о-во России, 2002. 350 c.

26. Селевко Г. К. Современные образовательные технологии: учеб. пособ. М.: Народное образование, 1998. 256 с.

27. Сериков В. В. Личностно ориентированное образование: поиск новой парадигмы:: монографиия. М.: Волгоградск. гос. пед. ун-т, 1998. $182 \mathrm{C}$

28. Якиманская И. С. Технология личностно-ориентированного образования. М.: Сентябрь, 2000. 130 с.

\section{References}

1. Bekh, I.D. (1999). Education of the growing personality on the basis of the new methodology [Vykhovannia pidrostaiuchoi osobystosti na zasadakh novoi metodolohii]. Pedagogy and psychology [Pedahohika i psykholohiia], 5-14. [in Ukrainian]

2. Bielykh, O.M. (2016). Features of management activities in the education system. [Osoblyvosti upravlinskoi diialnosti v systemi osvity]. Current issues of education and science [Aktualni pytannia osvity i nauky]. KhOHOKZ, Kharkiv, 34-38. [in Ukrainian]

3. Zhyhailo, O, Rudnyk, T. (2016). Features of the use of textbooks at different stages of mathematics lessons in primary school. [Osoblyvosti vykorystannia navchalnykh posibnykiv na riznykh etapakh uroku matematyky u pochatkovii shkoli]. Current issues of the humanities [Aktualni pytannia humanitarnykh nauk], 16, 316-321. [in Ukrainian]

4. Lukina, T. (2007). Measurement and management of quality education: educational and methodical materials. [Vyminuvannia y upravlinnia yakistiu osvity: navchalno-metodychni materialy]. Ekspres-obiava, Kyiv, 50. [in Ukrainian]

5. Lukina, T. (2006). Monitoring of quality education: theory and practice. [Monitorynh yakosti osvity: teoriia i praktyka]. Shkinyi svit; Kyiv, 128. [in Ukrainian]

6. Liashenko, O.I., Lukina, T.O., Bulakh, I.Ye., Mruha, M.R.. (2012). Methods and technologies for evaluating the activities of a secondary school [Metodyka i tekhnolohii otsiniuvannia diialnosti zahalnoosvitnoho navchalnoho zakladu: posibnyk]. Ped. dumka, Kyiv, 160. [in Ukrainian]

7. Mykytiuk, O.M. (2004). Theory and practice of organization of research work in higher educational institutions of Ukraine. Teoriia i praktyka orhanizatsii naukovo-doslidnoi roboty u vyshchykh navchalnykh zakladakh osvity Ukrainy]. In-t pedahohiky APN Ukrainy, Kyiv, 42. [in Ukrainian]

8. Ovchanuk, O.V. (2004). Competence approach in modem education: world experience and Ukrainian perspectives. [Kompetentnisnyi pidkhid u suchasnii osviti: svitovyi dosvid ta ukrainski perspektyyy]. K.I.S., Kyiv, 112. [in Ukrainian]

9. Orshanskyi, L. (2016). On the need for radical changes in the field of national education. [Pro potrebu kardynalnykh zmin u haluzi vitchyznianoi osvity]. Current issues of the humanities [Aktualni pytannia humanitarnykh nauk], 16, 371-378. [in Ukrainian]

10. Pasternak, T.A. (2007). Educational technologies in a modern higher education institution. Nykhovni tekhnolohii u suchasnomu vyshchomu navchalnomu zakladi] New learning technologies: scientific and methodical collection. [Novi tekhnolohiyi navchannia: naukovo-metodychniy zbimyk]. In-t innovatsiinykh tekhnolohii i zmistu osvity, Kyiv, 47, 97-102. [in Ukrainian]

11. Piekhota, O.M., Kiktenko, A.Z., Liubarska, O. M. (2004). Educational technologies. [Osvitni tekhnolohii]. A.S.K., Kyiv, 256. [in Ukrainian]

12. Pometun, O., Pyrozhenko. L. (2002). Interactive leaming technologies: theory and practice. [Interaktyni tekhnolohii navchannia: teoria i praktyka]. Kyiv, 136. [in Ukrainian]

13. Pometun, O., Pyrozhenko, L. (2004). A modem lesson. Interactive leaming technologies. [Suchasnyi urok. Interaktynni tekhnolohii navchannia]. Kyiv, 192. [in Ukrainian]

14. Sazonenko, H.S. (2000). Promising educational technologies. [Perspektyuni osvitni tekhnolohii]. Hopak, Kyiv, 560. [in Ukrainian]

15. Sysoieva, S.O. (1994). Fundamentals of pedagogical creativity of the teacher. [Osnovy pedahohichnoi tvorchosti vchytelia]. ISDOU, Kyiv, 112. [in Ukrainian]

16. Suxomlyncka, O.V. (2002). Periodization of pedagogical thought in Ukraine: towards a new dimension. [Periodyzatsiia pedahohichnoi dumky v Ukraini: kroky do novoho vymin]. Development of pedagogical and psychological sciences in Ukraine 1992-2002. [Rozvytok pedahohichnoi i psyholohichnoi nauk v Ukpaini 1992-2002]. OVC, Kharkiv, ch. 1, 37-54. [in Ukrainian]

17. Trush, N.I. (2008). On the dialectic of the relationship between didactic principles of scientificity and accessibility in the process of teaching mathematics. [Pro dialektyku vzaiemovidnoshennia dydaktychnykh pryntsypiv naukovosti ta dostupnosti $\vee$ protsesi navchannia matematyky]. e-journal "Pedagogical science: history, theory, practice, development trends". [e-zhurnal "Pedahohichna nauka: istoriia, teoriia, praktyka, tendentsii rozvytku"], 2. [in Ukrainian]

18. Law of Ukraine "On Education" dated 09/05/2017 № 2145-VIII. Holos Ukrainy. Holos Ukrainy, 10-22. [in Ukrainian]

19. Ukraine really needs NUS reform - PISA results confirm this and indicate how to make change more effective. RReforma NUSh diisno potribna Ukraini - rezultaty PISA pidtverdzhuiut tse i vkazuiut, yak zrobyty zminy efektywnishymy]. URL : https://mon.gov.ua/ua/news/reforma-nush-dijsno-potribna-ukrayini-rezultati-pisa-pidtverdzhuyut-ce-i-vkazuyut-yak-zrobiti-zmini- 
efektivnishimi (acceded 20.12.2019). [in Ukrainian]

20. Gal'perina, P.Ya., Taly’zinoj, N. F. (1972). Learning Management [Upravlenie poznavatel'noj deyatel'nost'yu uchashhikhsya]. University of Moscow, Moscow, 262. [in Russian]

21. Kal'nej, V.A., Shigov, S.E. (1998). Education Quality Monitoring. [Monitoring kachestva obrazovaniya]. Vologda:, Moscow, 202. [in Russian]

22. Klarin, M.V. (2000). Interactive learning is a tool for learning new experiences. [Interaktivnoe obuchenie - instrument osvoeniya novogo opy ta] Pedagogy [Pedagogika], 7, 43-48.

23. Lerner, I.Ya. (1981). Didactic foundations of teaching methods. [Didakticheskie osnovy’ metodov obucheniya]. Pedagogika, Moscow, 186.

24. Lerner, I.Ya. (1980). The learning process and its patterns [Proczess obucheniya i ego zakonomernosti], Znanie, Moscow, 96.

25. Potashnik M.M. (2002). The quality of education: problems and management technologies (In questions and answers). [Kachestvo obrazovaniya: problemy` i tekhnologii upravleniya (V voprosakh i otvetakh)]: Ped. o-vo Rossii, Moscow, 350.

26. Selevko, G.K. (1998). Modern educational technology [Sovremenny`e obrazovatel'ny`e tekhnologii]. Narodnoe obrazovanie, Moscow, 256.

27. Serikov, V.V. (1998). Person-oriented education: the search for a new paradigm [Lichnostno orientirovannoe obrazovanie: poisk novoj paradigm]. Volgogradsk. gos. ped. un-t, Moscow, 182.

28. Yakimanskaya, I.S. (2000). Student-centered education technology [Tekhnologiya lichnostno-orientirovannogo obrazovaniya]. Sentyabr', Moscow, 130.

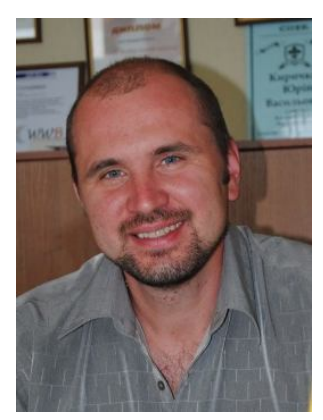

\section{Киричков Юрій Васильович.}

Директор, Політехнічний ліцей Національного технічного університету України "Київський політехнічний інститут" м. Києва, просп. Перемоги, 37, м. Київ, Україна, 03056.

Тел. +38(044)204-94-72. E-mail: plkpi@ukr.net

\section{Kyrychkov Yuriy Vasyliovych}

Principal, Polytechnic Lyceum of National Technical University of Ukraine 'Kyiv Polytechnic Institute'

37, Prosp. Peremohy, Kyiv, Ukraine, 03056

Tel. +38(044)204-94-72. E-mail: plkpi@ukr.net

ORCID: 0000-0001-7205-1075

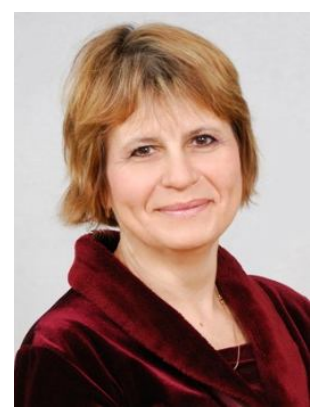

\section{Кофранова Олена Вікторівна}

д-р пед. наук., канд. хім. наук., професор кафедри геоінженерії,

Національний технічний університет України "Київський політехнічний інститут імені Ігоря Сікорського" (КП ім. Ігоря Сікорського), просп. Перемоги, 37, м. Київ, Україна, 03056.

Тел. +38(044)204-99-17. E-mail: alexina555@gmail.com

\section{Kofanova Olena Viktorivna}

Doctor in Pedagogy, PhD in Chemistry, Professor of Geoengineering Department, National Technical University of Ukraine 'Igor Sikorsky Kyiv Polytechnic Institute', 37, Prosp. Peremohy, Kyiv, Ukraine, 03056 Tel. +38(044)204-99-17. E-mail: alexina555@gmail.com

ORCID: 0000-0002-9851-6392

\section{Citation (APA):}

Kyrychkov, Yu., Kofanova, O. (2020). Motivational component and modern trends for quality assurance of mathematical and natural education of pupils - prospective entrants of technical higher education institutions. Engineering and Educational Technologies, 8 (2), 30-42. doi: https://doi.org/10.30929/2307-9770.2020.08.02.03

\section{Цитування (ДСТУ 8302:2015):}

Киричков Ю. В., Кофанова О. В. Мотиваційна складова і сучасні тенденції забезпечення якості математично-природничої освіти школярів - майбутніх абітурієнтів технічних закладів вищої освіти / Інженерні та освітні технології. 2020. Т. 8. № 2. С. 30-42. doi: https://doi.org/10.30929/2307-9770.2020.08.02.03

Обсяг статmі: $\quad$ сторінок-13 ; умовних друк. аркушів - 1,883. 